\title{
The Modern Practice of Intervention by Invitation in Africa and Its Implications for the Prohibition of the Use of Force
}

\author{
Erika de Wet*
}

\begin{abstract}
* Appointed SARCHI Professor of International Constitutional Law and Co-Director of the Institute for International and Comparative Law in Africa, Faculty of Law, University of Pretoria, South Africa; Honorary Professor, Faculty of Law, University of Bonn. Email: erika.dewet@up.ac.za. The research was undertaken in the context of a fellowship at the Stellenbosch Institute for Advanced Study. The author would like to thank Dire Tladi and Jure Vidmar for comments to an earlier draft. All electronic sources were last accessed on 20 September 2015.
\end{abstract}

\begin{abstract}
This article examines how two prominent criteria for permissible military intervention by invitation as developed in doctrine are currently implemented by states as well as how this impacts the prohibition of the use of force. Controversies concern, in particular, the determination of the authority entitled to extend the invitation, as recently illustrated by the Russian claim that its military intervention in the Crimea was based on the invitation of (former) President Yanukovych. Does the inviting authority need to enjoy democratic legitimacy and/or be in de facto control of a state's territory? Furthermore, it remains highly contentious whether an invitation for forcible intervention may be extended during a civil war. By analysing modern state practice in Africa - where most of the contemporary invitations for military assistance occur - and comparing it with recent developments in other regions, the author concludes that effective control rather than democratic legitimacy is (still) the point of departure for determining the legitimate government of a state. Once recognized, incumbent governments enjoy a large discretion when inviting military assistance from foreign governments. They seem to retain the right to military assistance even in situations of civil war and while exercising limited control over the territory.
\end{abstract}

\section{Introduction}

In recent years and in particularly since 9/11, much attention has been devoted to the evolution of the concept of self-defence in international law. ${ }^{1}$ It is a frequently used (and arguably abused) exception to the prohibition of the use of force in Article 2(4) of the Charter of the United Nations (UN Charter) and in customary international law. At the same time, limited scholarly attention has been devoted to another avenue for circumventing the prohibition of the use of force, despite its frequent use in practice particularly in Africa. It concerns military (forcible) intervention by invitation, which in 2011 recently formed the object of a resolution of the Institut de Droit International (IDI). In its 2011 Resolution on Military Assistance on Request, the IDI defined military intervention by invitation as direct military assistance by the sending of armed forces by one state to another state upon the latter's request. ${ }^{2}$ Since a 'request' implies the free expression of the will of the requesting state, some individuals have argued that this type of military intervention falls beyond the scope of the prohibition of the use of force. ${ }^{3}$ This would imply that due to the consent of the requesting state, there is no intervention against the political independence or territorial integrity of a state. Stated differently, military intervention by invitation would not constitute an 'exception' to the prohibition of the use of force in the proper sense, as the 
term 'exception' suggests that the type of military action in question would in principle be covered by the prohibition of the use of force.

According to another (in this contribution, preferred) line of argument, the reference to force 'against the territorial integrity or political independence' also covers military intervention on request, unless it is certain that the request does not undermine the territorial integrity or political independence of the requesting state. The mere fact that the forcible intervention was requested by the state does not in and of itself imply that its territorial integrity or political independence was not violated. ${ }^{4}$ For example, a military intervention on request that violated the right to self-determination recognized, inter alia, in Articles 1(2) and 55 of the UN Charter, would constitute an intervention 'against the political independence' of the requesting state. It would constitute a violation of Article 2(4) of the UN Charter, regardless of the fact that the intervention was based on state consent. ${ }^{5}$ If interpreted in this manner, permissible intervention by invitation is indeed an exception to the prohibition of the use of force.

The conditions under which military intervention by invitation remains in accordance with the territorial integrity and political independence of a state remains highly disputed among scholars. Controversies concern, in particular, the determination of the authority entitled to extend the invitation. For example, Russia, inter alia, justified its military intervention in the Crimea in March 2014 with the argument that it was invited by the democratically elected (although by then ousted) Ukrainian President Viktor Yanukovych. ${ }^{6}$ This raises the question whether the inviting authority needs to enjoy democratic legitimacy and/or be in de facto control of a state's territory. An additional vexing question concerns the type of situations in which such an invitation may be extended, notably whether it may be extended during a civil war.

The practical implications of these challenges have acquired considerable relevance in Africa in recent years, where military intervention by African states in other African states has become a frequent occurrence since the end of the Cold War. One example at the time of writing concerned the military intervention by Uganda in South Sudan at the invitation of the South Sudanese government. ${ }^{7}$ In addition, formal support for intervention by invitation is found in Article 4(j) of the Constitutive Act of the Africa Union (AU) of 2000, which recognizes the right of member states to request intervention from the $A U$ in order to restore peace and security. ${ }^{8}$

The purpose of this article is to examine how the two above-mentioned controversies regarding intervention by invitation are currently playing out in Africa; whether this practice differs considerably from intervention by invitation in other regions and what the implications of these developments would be for the prohibition of the use of force. The subsequent analysis first examines the criteria for determining the authority entitled to extend the military invitation. While the dominant view still is that only the recognized government may extend such an invitation, it has become increasingly contested if and to what extent this government must exercise effective control and/or whether lack of control can be compensated for, or even outweighed by, the incumbent government's (lack of) democratic legitimacy. Similarly, the type of control required by a government in order to be labelled as being 'effective' is open to debate. Thereafter, the analysis turns to the type of 
hostilities within which military intervention by invitation is permitted. It examines, in particular, whether state practice supports the doctrinal position that such an invitation is only permitted in hostilities that have not yet crossed the threshold of a civil war. Finally, the article considers whether the manner in which intervention by invitation is currently applied by states is having an eroding effect on the prohibition of the use of force. If an exception to the rule (prohibition) is extensively applied, it necessarily reduces the scope of the prohibition.

\section{The Authority Entitled to Extend an Invitation for Military Intervention}

It is generally accepted that the only authority within a state entitled to extend an invitation for military assistance to another state, whether in the form of troops or arms, is the internationally recognized de jure government. Even though the formal announcing of the recognition of governments has fallen increasingly out of fashion since the 1980s and the term recognition may seem outdated, states in practice still recognize governments (albeit implicitly) through dealing with them as such. A de jure recognized government would be the authority whose representatives are accepted in international organizations, accredits ambassadors, can legally enter into treaties and can legally dispose of the states' assets and natural resources. ${ }^{9}$

The illegality of direct military support to non-state actors has long since been articulated in various resolutions of the United Nations General Assembly (UNGA) and confirmed by the 1986 Nicaragua decision of the International Court of Justice (ICJ). ${ }^{10}$ This decision further confirmed that indirect support in the form of arming and training of the contras can amount to the threat or use of force against Nicaragua. ${ }^{11}$ Although the jurisdiction of the ICJ in the Nicaragua case was concerned with the interpretation and application of the customary prohibition of the use of force, and not Article 2(4) of the UN Charter as such, the decision did confirm an overlap in content between the customary rule and Article 2(4) of the UN Charter. ${ }^{12}$ It is therefore fair to conclude that the sending of armed forces in support of rebel forces, as well as their training and arming, can amount both to the violation of the customary prohibition of the use of force and Article 2(4) of the UN Charter.

Recently, the unique right of the de jure government to invite military support came under pressure, when various Western and Arab countries expressed themselves in favour of military support to the Syrian Opposition Coalition (SOC). For example, in January 2013, the United Kingdom's (UK) Foreign Secretary suggested that European Union (EU) countries should consider providing arms to the opposition in Syria, as an option to save lives. ${ }^{13}$ In May 2013, the Council of the EU opened the door to the supply of arms to the Syrian opposition under certain conditions, ${ }^{14}$ although EU member states have thus far been reluctant to provide equipment beyond body armour and armoured vehicles. ${ }^{15}$

Other states, including Saudi Arabia and Qatar, have nonetheless provided the Free Syrian Army (which was regarded as the military wing of the SOC) with arms and funding. ${ }^{16}$ The US Congress has also approved the supply of weapons to anti-government forces subsequent to the chemical weapons attack near Damascus in August 2013. ${ }^{17}$ The Dutch government politically justified the supply of military equipment to the SOC in exceptional cases and under specific conditions on the lack of the legitimacy of the Assad regime and the broad 
recognition of the SOC as the legitimate representative of the Syrian people. ${ }^{18}$ In accordance with the reasoning of the Nicaragua decision, the arming of the Syrian opposition would amount to a violation of the prohibition of the threat or use of force under both customary international law and Article 2(4) of the UN Charter. ${ }^{19}$

\section{A The Role of Democratic Legitimacy in Recognizing a De Jure Government}

Traditionally, effective control has served as the point of departure for identifying the recognized de jure government of a state ${ }^{20}$ In accordance with this view, the fact that a particular government came into power by military coup, through an uprising of parts of the population or through civil war was irrelevant for the purpose of recognition. ${ }^{21}$ Rather than being concerned with the manner in which governmental power was acquired or exercised, recognition hinged on demonstrable and sustainable effective control over most of the territory and the state institutions, which would normally also necessitate control over the capital. ${ }^{22}$ Such control implied a certain amount of acquiescence on the part of the civilian population, in the sense that it refrained from attempts to overthrow the government. ${ }^{23}$ The effective control principle was thus based on the fiction that control resembles the acceptance (or at least acquiescence) of the population of the right of the incumbent government to represent the state as a whole. ${ }^{24}$ Recognition of a government could either take the form of a formal statement of recognition or (as has become common since the late 20th century) de facto dealings with the regime that was effectively in control over the territory. ${ }^{25}$

This approach, according to which facts on the ground were decisive for determining the status of government, has been hailed as providing the only clear basis for the conduct of international relations in the decentralized international legal order. ${ }^{26}$ However, by the end of the Cold War, calls for a right to democratic governance and accountability for human rights atrocities gained new momentum, as evinced, inter alia, by democratic elections in various Central and Eastern European states and the creation of the International Criminal Tribunal for the former Yugoslavia (ICTY) and Rwanda (ICTR), respectively. ${ }^{27}$ As a result of this new thrust towards democratic governance and respect for human rights, traditional recognition practices based on a 'might is right' approach came under increasing attack in literature. Instead, the democratic legitimacy of the new government was propagated as the appropriate criterion for recognition. ${ }^{28}$

Although there is no unitary definition of democracy in the scholarly debate, a procedural definition that focuses on a free and fair electoral process seems to constitute the smallest common denominator. References to democracy in the international legal discourse tend to regard free and fair elections as a minimum requirement for democratic governance. ${ }^{29}$ This approach also found resonance in state and institutional practice in the $1990 \mathrm{ss}^{30}$ The international community rejected the internal overthrow of Haitian President Jean-Bertrand Aristide in 1991 and that of Sierra Leonean President Ahmad Tejan Kabbah in 1997. ${ }^{31}$ In both instances, the governments were democratically elected by a very large margin and subsequently took control of the state apparatus, but only to be ousted by military coups shortly afterwards. Despite the loss of effective control, both governments continued to be recognized by the international community as the legitimate government. ${ }^{32}$ 
In addition, in both instances these ousted leaders subsequently requested foreign military assistance in order to regain power. Whether the subsequent military interventions were indeed based on these invitations remains disputed. In the case of Haiti, the military intervention was also underpinned by United Nations Security Council (UNSC) Resolution 940 of 31 July 1994, which was adopted under Chapter VII of the UN Charter. In the case of Sierra Leone, the military intervention by the Economic Community of West African States (ECOWAS) at the request of the exiled Kabbah government ${ }^{33}$ was subsequently praised by UNSC resolutions, without explicitly authorizing the use of force under Chapter VII of the UN Charter. ${ }^{34}$ Even so, some have argued that the ECOWAS intervention in Sierra Leone is a case of ex post facto UNSC authorization. ${ }^{35}$ However, the disputed legal basis of the military interventions in Haiti and Sierra Leone is arguably not decisive for the point at issue, namely that in both instances the democratic legitimacy of the government carried more weight for the purpose of recognition than actual effective control. ${ }^{36}$

The Haitian and Sierra Leonean incidents were accompanied by institutional changes within the Organization of American States (OAS) and the AU. Since the current contribution focuses on Africa, it will suffice to say that within the OAS these developments culminated in the Inter-American Democratic Charter of 2001. Article 19 determines that:

an unconstitutional interruption of the democratic order or an unconstitutional alteration of the constitutional regime that seriously impairs the democratic order in a member state, constitutes, while it persists, an insurmountable obstacle to its government's participation in sessions of the Organization. ${ }^{37}$

It is, however, worth noting that the OAS has not been consistent in acting on this article. While it did condemn the 2009 coup against Honduran President Manuel Zeleya, ${ }^{38}$ it remained reluctant to act during constitutional interruptions in Peru, Guatemala, Paraguay, Ecuador and Venezuela. ${ }^{39}$

As far as the AU is concerned, its Constitutive Act of 2000 condemns any unconstitutional change of government in Article 4(p). ${ }^{40}$ In 2007, the AU also adopted the African Charter on Democracy, Elections and Governance. ${ }^{41}$ In Article 25, this Charter calls for the suspension of governments that come into power by unconstitutional means. It further provides for wide-ranging measures in reaction to an unconstitutional change of government, including the non-participation in elections and judicial proceedings within the $\mathrm{AU}$ as well as economic sanctions. In February 2012, this Charter entered into force after mustering the required 15 ratifications and is currently binding on 23 members states. ${ }^{42}$ While this treaty does not yet apply to the remaining 31 members of the $A U$, they do fall under the scope of Article 4(p) of the AU Constitutive Act. However, the AU itself has not been consistent in its enforcement of Article 4(p). While the AU sanctioned the unconstitutional seizure of power in Togo in 2005, in the Comoros in 2008, in Guinea in 2008, and in Madagascar in 2009, the AU merely condemned similar behaviour in São Tomé and Príncipe in 2003 and in Côte d'Ivoire in $2010 .^{43}$

Furthermore, by 2009 (just before the so-called Arab Spring) no less than eight African regimes that have come into power by coups were allowed to address the UNGA without any objection by the $\mathrm{AU} .^{44}$ This continued tolerance of coup regimes in Africa is sometimes 
also accompanied by the ambivalent treatment of popular rebellion against authoritarian regimes on the continent as well as of democratically elected ones. The AU's unclear position on these issues became evident during the early days of the Arab Spring, when authoritarian regimes in Egypt and Libya faced popular revolt. Similar inconsistencies plagued the behaviour of other states regarding recent developments in these two countries.

In the case of Libya, the revolt culminated in the North Atlantic Treaty Organization's (NATO) military intervention subsequent to the adoption of UNSC Resolution 1973 of 17 March 2011 under Chapter VII of the UN Charter and the ousting of the Qaddafi regime. Despite disagreement within the $A U$ about the extent to which regime change was foreseen by Resolution 1973 (2011), ${ }^{45}$ it subsequently did recognize the National Transitional Council of Libya (NTC) as the legitimate government of Libya. In a statement in October 2011, the $\mathrm{AU}$ - while underscoring the uniqueness of the situation in Libya and the exceptional circumstances surrounding it - authorized the NTC to occupy the seat of Libya in the AU and its organs. ${ }^{46}$ Outside of the AU, the TNC was already recognized as the legitimate governing authority by 32 countries (including the United Kingdom and the USA) on 15 July $2011 .{ }^{47}$

The fact that the NTC did not come to power through a democratic electoral process prevented neither the AU nor the 32 states forming part of the Libya Contact Group from recognizing it as the legitimate government of Libya. In the case of the $A U$, the recognition took place at a time when the NTC was in effective control of most of the territory - a fact that may have contributed to the AU's acquiescence in the NTC's status as the recognized government. ${ }^{48}$ However, doubts have been expressed whether the NTC had been in effective control at the time of its recognition by the 32 states forming part of the Libya Contact Group. As a result, it would have been premature and illegal interference in the affairs of another state. ${ }^{49}$ The United Nations (UN) accepted the credentials of the NTC on 16 September $2011 .^{50}$

As far as Egypt is concerned, the AU neither condemned the mass demonstrations against the authoritarian regime of President Hosni Mubarak in February 2011, nor did it explicitly come out in support of popular uprisings in favour of democratic elections. ${ }^{51}$ Subsequently, the $A U$ did reject the ousting of democratically elected Egyptian President Mohamed Morsi in 2013 as an unconstitutional change of government. He was removed from power by the military, barely one year after winning the Egyptian elections in 2012. At the time of his removal, President Morsi was facing extensive popular protest, and millions of Egyptians demanded his resignation. ${ }^{52}$ Even so, the $\mathrm{AU}$ underscored that the overthrow of the democratically elected president was unconstitutional, and it suspended Egypt from its activities until constitutional democracy was restored. ${ }^{53}$ On the other hand, Western countries, including the USA and members of the EU, were reluctant to call the ousting a coup or demand President Morsi's reinstatement. ${ }^{54}$

Inconsistencies also plagued African and other responses to the respective coups in GuineaBissau (one of the 15 parties to the African Charter on Democracy, Elections and Governance) and Mali in 2012. While the AU condemned the coup and suspended GuineaBissau from its activities, ${ }^{55}$ ECOWAS supported a process of cooperation with the coup government aimed at restoring democracy, despite its condemnation of the coup. ${ }^{56}$ The UN 
and the EU condemned the coup and called for a reinstatement of the democratically elected government. ${ }^{57}$ In the case of Mali, the junta responsible for the military coup against President Amadou Touré in March 2012 was subsequently accommodated in the transitional government that took office in August $2012 .^{58}$ This government was swiftly recognized by the international community, and the UN also endorsed its request for military assistance by France, due to the deterioration of the security situation in the north of Mali. ${ }^{59}$ The most recent coup in Africa (at the time of writing) concerned the ousting of former President François Bozize of the Central African Republic (CAR) by the Seleka rebels in March 2013. In this instance, the AU suspended the CAR from its activities and imposed sanctions, travel restrictions and an asset freeze on the Seleka's leaders in response to the coup. $^{60}$

In essence, the inconsistent state responses to unconstitutional change of government in Africa suggest that democratic legitimacy is not (yet) a requirement for recognition of a particular African government within the $A U$ or beyond. A violation of Article 4(p) of the $A U$ Constitutive Act or the African Charter on Democracy, Elections and Governance by seizing power in an unconstitutional manner would not necessarily result in the non-recognition of the culprit government within the AU or by other states. A similar reluctance to acknowledge the legal relevance of democratic legitimacy for the purpose of governmental recognition can be inferred from the reaction of states towards recent events in the Crimea. As mentioned at the outset of this article, Russia justified its military intervention in the Crimea in March 2014, inter alia, with the argument that it was requested by the democratically elected (but by then ousted) Ukrainian President Yanukovych. ${ }^{61}$ It is true that Yanukovych's own Parliament voted to remove him from power on 22 February 2014. However, this vote appeared to be unconstitutional as it did not confirm to the two-thirds majority requirement contained in the Ukrainian Constitution. Even so, no less than 100 states subsequently supported UNGA Resolution 262 of 27 March 2014 not to recognize the altered territorial status of the Crimea. Only 11 states (including Russia) voted against the resolution, while 58 states abstained. ${ }^{62}$

It is arguable that a resolution that was explicitly supported by more than half of the membership of the UN, while explicitly rejected by merely 11 states, can be interpreted as an implicit rejection of Yanukovych's claim that he continued to represent the democratically elected, and therefore legitimate, government of Ukraine. ${ }^{63}$ After all, had Yanukovych still been regarded as the head of state, an invitation to Russia to intervene militarily in the Crimea would not have resulted in a disruption or alteration of the territorial integrity and status of Ukraine. In conclusion, therefore, democratic legitimacy does not yet seem to be a requirement for recognition of governments in international law. Even though legal scholarship since the 1990s may have raised high hopes in this regard, state practice in support of such a requirement remains inconsistent. ${ }^{64}$ Democratic legitimacy is indeed one factor that can be taken into account when recognizing a particular government, but it has not yet replaced effective control as the point of departure for recognition.

\section{B The Meaning of 'Effective Control' for the Purpose of (Continued) Recognition}

The degree of control required for qualifying as being in 'effective control' and, therefore, constituting the de jure government of a state has also been subject to some controversy. 
The issue arises in particular where an incumbent, recognized government loses control over large parts of the territory to rebel forces. ${ }^{65}$ Practice indicates a tendency to presume continued effective control by the incumbent government, even in situations where it has lost control over (parts of) the territory. ${ }^{66}$

During the Cold War era, this presumption manifested itself, in particular, in situations where incumbent African governments of former British and French colonies were ousted by mutinous troops. The subsequent invitations for military assistance by these ousted governments to the former colonial powers in order to facilitate their reinstatement were by and large condoned by the international community. ${ }^{67}$ The initial loss of control over the territory and state institutions thus did not automatically terminate the right of the affected government to represent the state, including for the purpose of requesting military assistance.

The fact that limited military force was needed for the reinstatement of these governments and that their regimes were only interrupted for a brief period may have contributed to the acquiescence of the international community in the military interventions in question. ${ }^{68}$ However, modern state practice indicates that a presumption of effective control of the incumbent government also tends to prevail in situations where the loss of territorial control has persisted for some time. Some authors refer to the ECOWAS intervention in Liberia in August 1990 as an example, as it was preceded by an invitation by President Samuel Doe to ECOWAS to intervene militarily. ${ }^{69}$ At the time of the intervention, Doe's government in Liberia had already lost control of most of the territory to rebel forces subsequent to a rebellion commencing in December $1989 .{ }^{70}$ On the other hand, ECOWAS had also expressed grave concerns about the humanitarian situation in Liberia and other authors have interpreted ECOWAS's military action in Liberia as an intervention based on humanitarian grounds. ${ }^{71}$

A less ambivalent example concerned the $A U^{\prime}$ s response to an invitation by the Somali transitional federal government in January 2007, when establishing the African Union Mission in Somalia, a training and protection mission. ${ }^{72}$ Although the transitional government was weak and controlled far less territory than the rebels, they were regarded as the recognized government that could extend an invitation for military intervention to the $\mathrm{AU} .{ }^{73}$ In addition, when the Malian government lost control over the north of the country in 2012, it did not affect its position within the AU or the UN as the legitimate government that could extend an invitation for military intervention to other states. ${ }^{74}$

The only recent instance in Africa where the incumbent government's loss of control over parts of the territory went almost hand in hand with its de-recognition as the legitimate government, concerned the Qaddafi regime in Libya. However, this development was a direct result of the adoption of UNSC Resolution 1973 of 17 March 2011, which authorized military force under Chapter VII of the UN Charter against the incumbent Qaddafi regime. Since the NATO countries implementing the military mandate interpreted the mandate as authorizing regime change, ${ }^{75}$ these states and their allies were bound to de-recognize the Qaddafi regime. 
As far as other regions are concerned, a similar fiction of effective control can be observed in Afghanistan. In September 2014, the Ghani government signed a bilateral security agreement with the USA, consenting to the military presence of the USA in Afghanistan for the purpose of, inter alia, countering Al Qaida. ${ }^{76}$ The fact that the Afghan government did not have effective control over all of Afghanistan did not seem to pose an obstacle in signing the agreement. ${ }^{77}$ Similarly, the Iraqi government requested military support (air strikes) from the USA in June 2014 at a time when the Islamic state movement was already in control of parts of Iraq. ${ }^{78}$ The fate of the Yanukovych government in Ukraine in March 2014 constituted an exception to the presumption of continued effective control of an incumbent government. This would relate in part to the fact that the political interests of Russia and the Western powers were diametrically opposed at the time of Yanukovych's removal, unlike in the other situations referred to earlier.

On the whole, it seems fair to conclude that once recognized internationally, an incumbent government is in principle presumed to remain in effective control - also for the purpose of inviting military assistance - even in situations where such control becomes fictitious. This presumption or fiction of effective control tends to prevail as long as there is a broad consensus within the international community that the incumbent government is politically the most suitable entity to represent the state, without any clear alternative to take its place. ${ }^{79}$

\section{The (Im)permissibility of Intervention by Invitation during a Civil War}

It is often argued that the incumbent government's right to invite foreign military assistance - notably in the form of foreign troops - only exist as long as the level of violence has not crossed the threshold of a 'civil war'. ${ }^{80}$ Historically the term 'civil war' was often used in relation to situations of belligerency, which was one of three categories used to describe violence within a state - the other two being rebellions and insurgencies. ${ }^{81}$ Rebellions were isolated incidents that could be brought under control with limited use of force.

Insurgencies implied more sustained violence by the insurgents, coupled with difficulties in suppressing it and an uncertain outcome. For a state of belligerency to be declared, there had to be a state of general hostilities as well as control over, and administration of, a substantial part of the territory by the opposition forces. ${ }^{82}$ The relevance of these distinctions for foreign intervention on the side of the incumbent government was that it was permitted in relation to rebellions, while controversial once the violence escalated into an insurgency. The uncertain outcome combined with some loss of territory questioned the legitimacy of the incumbent government for the purpose of inviting foreign military support. $^{83}$

In modern international law, the term 'non-international armed conflict' (NIAC) is preferred to 'civil war', ever since the inclusion of the phrase 'armed conflict not of an international character' in common Article 3 of the 1949 Geneva Conventions. ${ }^{84}$ Although the Conventions do not define this phrase, the drafting history indicates that the drafters used the term civil war when referring to the threshold for applicability of common Article $3 .^{85}$ Moreover, the drafting history further indicates that the drafters interpreted the notion of civil war broadly for the purposes of determining the threshold of applicability of common Article 3. The article operates at the level of internal hostilities that have escalated beyond 
riots and disturbances into an insurgency and was not to be limited to situations of belligerency. ${ }^{86}$ This threshold, which is lower than belligerency, was subsequently also confirmed by the Protocol Additional to the Geneva Conventions of 12 August 1949, and Relating to the Protection of Victims of Non-International Armed Conflicts (Additional Protocol II), which excluded internal disturbances such as riots from its application. ${ }^{87}$ Subsequent jurisprudence of international criminal tribunals confirmed that the threshold of a NIAC is crossed when the internal hostilities have been of a protracted nature, have reached a certain level of gravity ${ }^{88}$ and where the rebel groups have possessed a certain level of organization. ${ }^{89}$

It is noteworthy that the resolutions of the UNGA pertaining to foreign military intervention between 1949 and 1970 still referred to terms such as 'civil war' and 'civil strife'. The first UNGA Resolution 375 (1949) on the rights and duties of states determined in Article 4 that every state had the duty to refrain from fomenting 'civil strife' in the territory of another state and to prevent the organization within its territory of activities calculated to foment such civil strife. ${ }^{90}$ This resolution was followed by UNGA Resolution 2131 (1965) on nonintervention in the internal affairs of states. The second sentence of Article 2 specifically prohibits any third state from interfering in a 'civil war' taking place within another state. ${ }^{91}$ Subsequently, UNGA Resolution 2625 (1970) on friendly relations reaffirmed the duty of every state to refrain from organizing, instigating, assisting or participating in acts of 'civil strife' or terrorist acts in another state or acquiescing in organized activities within its territory directed towards the commission of such acts, when the acts referred to in the present paragraph involve a threat or use of force. ${ }^{92}$

It is not clear from the wording of the UNGA resolutions whether 'civil strife' would amount to 'civil war' as the resolutions do not define the terms. However, it is arguable that they can be regarded as synonyms, since UNGA Resolution 2625 (1970) clearly linked 'civil strife' to acts that involve the use of force. Moreover, the wording of the 2011 Resolution of the IDI supports the conclusion that these terms are covered by the term NIAC. While its 1975 Resolution dealing with military assistance on invitation underscored the importance of non-intervention in 'civil wars', ${ }^{93}$ its 2011 Resolution refers to the term NIAC. Article 2(1) limits permissible military assistance on request to:

situations of internal disturbances and tensions, such as riots, isolated and sporadic acts of violence and other acts of a similar nature, including acts of terrorism, below the threshold of non-international armed conflict in the sense of Article 1 of Protocol II Additional to the Geneva Conventions relating to the Protection of Victims of Non-International Armed Conflicts of $1977 .^{94}$

If one accepted that the terms civil war and civil strife in the UNGA had to be interpreted synonymously with a NIAC, military intervention by invitation of the incumbent government would only be permissible where the violence within the state was sporadic and isolated instances of riot-not unlike the 'rebellions' in earlier times. This conclusion is supported by the debate in doctrine pertaining to the right of self-determination. It is well recognized that the right to self-determination acknowledges the right of colonial peoples to independence. ${ }^{95}$ In addition, doctrine acknowledges the right of peoples within an independent state to determine its own government with no outside interference. ${ }^{96}$ 
One line of argument interprets the right of self-determination as vesting in the state as an abstract entity (consisting of a population and territory) rather than in the people(s) within the state to choose a specific form of governance. ${ }^{97}$ In addition, it regards the rights of selfdetermination and the customary right to non-intervention as two sides of the same coin, as this right implies the right of states to make choices about their political, economic, social, and cultural system without external interference. ${ }^{98}$ In line with this reasoning, the right to self-determination does not necessarily imply that a government within a state has to come about through free and fair elections. ${ }^{99}$ Instead, the government can also come about through a civil war (NIAC). It is decisive, however, that hostilities intended to overthrow the established regime must be decided without external interference, as such interference would violate the right of non-intervention. ${ }^{100}$

Another line of reasoning emphasizes that the right to self-determination vests in the people(s) within a state, especially since its codification as a human right. ${ }^{101}$ This implies a right to be represented by the government that claims for itself the right to, inter alia, invite foreign military assistance. In situations where the population has made clear its intent to overthrow the incumbent government through civil war (NIAC), the incumbent government could not claim popular acceptance. ${ }^{102}$ Where an incumbent government has lost control over parts of its population and territory, it would lack the level of representativeness required by the right to self-determination for the purpose of inviting any foreign military assistance. Any foreign assistance to the incumbent under such circumstances would coerce the outcome of the internal contest for political power and thereby violate the right to selfdetermination. ${ }^{103}$

Whichever of the above interpretations of self-determination (which in itself remains a heavily contested issue in international law) one prefers, both set a limit to the right of the incumbent government to receive foreign military assistance during civil war. ${ }^{104}$ Both lines of reasoning further imply that a violation of the right to self-determination in the form of foreign military assistance during a civil war (NIAC) can simultaneously result in a violation of the prohibition of the use of force. In relation to both norms, the protection of the political independence of the state plays a central role. ${ }^{105} \mathrm{~A}$ military intervention that violates the right to self-determination by preventing a state (and its peoples) from determining its political future independently is bound to amount to the use of force against the political independence of a state, as prohibited in Article 2(4) of the UN Charter and in customary international law. ${ }^{106}$

Determining in practice when hostilities within a state have escalated beyond mere internal disturbances and constitute a civil war (NIAC) remains highly challenging. Governments embroiled in hostilities have persistently been unwilling to admit that the threshold of a NIAC has been crossed, as they see this as legitimation for opposition forces. ${ }^{107}$ Similarly, third states are often also reluctant to acknowledge the existence of a NIAC. ${ }^{108}$ The result is that, in practice, military intervention on the invitation of the incumbent government is also tolerated in situations that may actually have escalated into a NIAC. ${ }^{109}$ For example, the military presence of Uganda on the invitation of the Democratic Republic of Congo (DRC) occurred in a context that at least at times crossed the threshold of a NIAC. Yet in the case concerning Armed Activities on the Territory of the Congo (Democratic Republic of the Congo $v$. Uganda), the ICJ regarded the consent (during the time that it actually existed) as a valid 
basis for the Ugandan presence. ${ }^{110}$ Similarly, the UNSC expressed its concern about the escalating violence in South Sudan but without calling for the withdrawal of the Ugandan forces. ${ }^{111}$

Another pertinent example concerns the French intervention on the invitation of Mali in January 2013. This invitation was issued when it became clear that the UNSC's authorized deployment of an African-led International Support Mission in Mali (AFISMA) ${ }^{112}$ would not become a reality in practice. ${ }^{113}$ In its official letter sent to the UNSC on the same date, France stated that its intervention was in response to a request for assistance from the interim president of the Republic of Mali, Dioncoundra Traoré. It noted that Mali was facing terrorist elements from the north who were threatening the territorial integrity and the very existence of the state and the security of its population. ${ }^{114}$ The French presence was thus depicted as combating terrorism, in an apparent attempt to legitimate the intervention. ${ }^{115}$ However, the fact remains that virtually all governments describe rebel forces as 'terrorists', but this depiction cannot in and of itself disqualify hostilities from constituting a NIAC. Where such terrorist acts go hand in hand with open, intense hostilities over a sustained period of time and with control over parts of the territory by rebel forces, as has been the case in Mali, suggestions that the French intervention was not intended to settle internal political strife in favour of the established government rings hollow. ${ }^{116}$ Even if the French intervention were not directed against all political factions opposing the government, ${ }^{117}$ it was most certainly directed at sustaining the incumbent government at a point where it had already lost a considerable amount of territory to Islamist factions. ${ }^{118}$

The fact that the hostilities in Mali have crossed the threshold of a NIAC did not seem to affect the legality of the invitation extended to France. The USA supported the intervention, emphasizing the consensus about the gravity of the situation and the right of the Malian authorities to seek 'what assistance they can receive'. ${ }^{119}$ Similarly, ECOWAS endorsed the decision of the UNSC to authorize a military intervention in Mali and thanked the French government for its initiatives to support Mali. ${ }^{120}$ Moreover, in its follow-up Resolution 2100 of 13 April 2013, the UNSC welcomed the French action in the preamble. ${ }^{121}$

Outside of Africa, a similar leniency towards intervention by invitation in situations that have crossed the threshold of a NIAC can be observed in Afghanistan and Iraq. The abovementioned bilateral security agreement between Afghanistan and the USA was adopted in a situation of long-standing, open hostilities with insurgents. ${ }^{122}$ Similarly, the Iraqi government requested military support (air strikes) from the USA in June 2014 during intense fighting with the ISIS movement, which was described by the UNSC as a large-scale offensive aimed at destabilizing the country. ${ }^{123}$ In essence, therefore, there is hardly any recent state practice supporting the view that states accept that they are barred from providing direct military support to a government embroiled in a civil war (NIAC). ${ }^{124}$ Instead, state practice seems to be very permissive of military support on the side of the incumbent government, despite its potentially eroding impact on the right to self-determination and the prohibition of the use of force.

Finally, it is worth noting that even where governments acknowledge that hostilities have escalated to a NIAC, they tend to justify military intervention on request on the ground that there has been prior foreign intervention against the government. Such support by third 
states can amount to an act of aggression under certain circumstances. ${ }^{125}$ Accordingly, the incumbent government can claim a right to receive military assistance from other states on the basis of the right to collective self-defence. ${ }^{126}$ The ongoing conflict in the DRC constitutes an example of a civil conflict fuelled by the outside involvement of many states. ${ }^{127}$ For example, when Angola, Namibia, and Zimbabwe intervened militarily in the DRC in August 1998, they relied on collective self-defence in support of President Kabila who requested assistance against the Congolese Tutsi rebels supported by Uganda and Rwanda. ${ }^{128}$

\section{Conclusion}

The above analysis confirms that the practice of intervention by invitation is firmly established in Africa. Unlike during the Cold War era, these interventions are not predominantly undertaken by the former colonial powers: the modern practice of intervention by invitation is, first and foremost, an intra-African phenomenon. An analysis of this practice further suggests that once a government has been internationally recognized as the legitimate representative of a state, it has extensive leeway for inviting direct military support from other states. There seems to be a presumption of its continued legitimacy for the purpose of inviting military assistance from other states. As long as there is no general agreement among third states as to whether any viable alternative government exists, the incumbent government may continue to exercise the right to forcible intervention - even in situations where its effective control over the state territory has become largely fictitious.

In the same vein, the practice of African states suggest that the right to forcible intervention does not seem to terminate when the conflict crosses the threshold of a civil war (NIAC), even though military intervention under these circumstances is bound to undercut the right to self-determination and the prohibition of the use of force, due to its impact on the political independence of the state in question. Although the practice of military intervention by invitation remains scarce outside of Africa, the current situations in Afghanistan and Iraq suggest a similar leniency towards the incumbent governments. In both states, the recognized government requested and received military support from third states while not in control of all of the state territory and amid hostilities that can hardly be described as mere riots or isolated instances of disturbances.

The leniency towards forcible interventions on the invitation of governments is, in part, an inevitable consequence of the inability of the UNSC and regional organizations such as the AU to establish effective collective peacekeeping measures in conflict-ridden countries. Yet it simultaneously undercuts the political independence of the people within a state. This in turn significantly reduces the scope of the right to self-determination and the prohibition of the use of force in Article 2(4) of the UN Charter and in customary international law. 


\section{Footnotes}

${ }^{1}$ See, e.g., G.P. Fletcher and J.D. Ohlin, Defending Humanity: When Force Is Justified and Why (2008);

Bethlehem, 'Principles Relevant to the Scope of a State's Right of Self-Defense against an Imminent or Actual Armed Attack by Non-State Actors', 106 American Journal of International Law (AJIL) (2012) 769; H.H. Koh, 'International Law in Cyberspace', Opinio Juris (18 September 2012), available at http://opiniojuris.org (last visited 20 September 2015).

${ }^{2}$ Institut de Droit International (IDI), Resolution on Military Assistance on Request (8 September 2011), Art. 1(a) and 1(b), available at www.idi-iil.org/idiE/navig_res_chon.html (last visited 20 September 2015). For its earlier work on the same topic, see IDI, Resolution on the Principle of Non-Intervention in Civil Wars (14 August 1975), Art. 1, available at www.idi-iil.org/idiE/resolutionsE/1975_wies_03_en.pdf (last visited 20 September 2015).

${ }^{3}$ Le Mon, 'Unilateral Intervention by Invitation in Civil Wars: The Effective Control Test Tested', 35 New York University Journal of International Law and Politics (NYJILP) (2003) 742; Wippman, 'Military Intervention, Regional Organizations and Host-State Consent', 7 Duke Journal of Comparative and International Law (1996) 2010; Bannelier and Christakis, 'Under the UN Security Council's Watchful Eyes: Military Intervention by Invitation in the Malian Conflict', 26 Leiden Journal of International Law (LIL) (2013) 860.

${ }^{4}$ Perkins, 'The Right to Counter-Intervention', 17 Georgia Journal of International and Comparative Law (1987) 184.

${ }^{5}$ Ibid., at $185-186$.

${ }^{6}$ See references in note 61 in this article.

${ }^{7}$ President Museveni of Uganda sent troops across the border at the invitation of President Salva Kiir shortly after fighting broke out between forces loyal to President Kiir and rebels in December 2013. The countries signed a Status of Forces Agreement between the Government of the Republic of Uganda and the Government of the Republic of South Sudan (10 January 2014), available at

www.sudantribune.com/IMG/pdf/status_of_forces_agreement-2.pdf (last visited 20 September 2015). The Ugandan Parliament also adopted a motion approving of the sending of troops to South Sudan at the request of the latter's government. See Motion for a Resolution of Parliament to Authorize his Excellency the President of the Republic of Uganda to Deploy Uganda People's Defence Forces to the Republic of Southern Sudan in Accordance with Article 210 of the Constitution and Section 40 of Uganda Peoples' Defence Forces Act, 2005 (14 January 2014), available at www.parliament.go.ug/new/index.php/documents-and-reports/daily-hansard (last visited 20 September 2015).

${ }^{8}$ African Union, Constitutive Act (1 July 2001), available at http://www.peaceau.org/uploads/au-act-en.pdf (last visited 20 September 2015). Art. 4(j) confirms '[t]he right of Member States to request intervention from the Union in order to restore peace and security'.

${ }^{9}$ See S. Talmon, Recognition of Governments in International Law: With Particular Reference to Governments in Exile (1998), at 3ff. For an analysis of the powers of the de jure government, see Talmon, 'Recognition of the Libyan National Transitional Council', 15 ASIL Insights (16 June 2011), available at www.asil.org/ (last visited 20 September 2015).

${ }^{10}$ GA Res. 3314 (XXIX), 14 December 1974, para. 3(g) confirmed that the sending by a third state of armed bands, groups, mercenaries or irregular forces that carry out armed force against another state can amount to an act of aggression. See also Military and Paramilitary Activities in and against Nicaragua (Nicaragua $v$. United States) (Nicaragua), Merits, 27 June 1986, ICJ Reports (1986) 14, para. 195.

${ }^{11}$ Nicaragua, supra note 10, paras 195, 228. 
12 Ibid., para. 188. See GA Res. 2131 (XX), 21 December 1965, para. 2, which condemned (support of) armed activities towards the violent overthrow of the regime of another state. See also Le Mon, supra note 3, at 752, 754; Wippman, supra note 3, at 214; D. Akande, 'Would It Be Lawful for European (or other) States to Provide Arms to the Syrian Opposition?', EJIL:Talk! (17 January 2013), para. 1, available www.ejiltalk.org/ (last visited 20 September 2015); Ruys, 'Of Arms and "Non-Lethal Assistance": Issues Surrounding Third-State Intervention in the Syrian Civil War', 13 Chinese Journal of International Law (ChJIL) (2014) 32.

${ }^{13}$ British Broadcasting Corporation (BBC), 'William Hague Says UK Could Start Arming Syrian Rebels', BBC News (10 January 2013), available at www.news.bbc.co.uk (last visited 20 September 2015); Akande, supra note 12, para. 1.

${ }^{14}$ Council of the EU, 'Council Declaration on Syria', 27 May 2013, available at www.consilium.europa.eu/uedocs/cms_data/docs/pressdata/EN/foraff/137315.pdf (last visited 20 September 2015).

${ }^{15}$ Ruys, supra note 12 , at 15.

${ }^{16}$ Ibid. , at 25.

${ }^{17}$ Ibid., at 16 .

18 'Volkenrechtelijke aspecten sanctieregime Syrië', Letter by the Dutch Foreign Minister to the House of Representatives, 4 June 2013, available at www.rijksoverheid.nl/documenten-enpublicaites/kamnerstukken/2013/06/04/kamerbrief-over-de-volkenrechtelijke-aspecten-van-hetsanctieregime-tegen-syrie.html/ (last visited 20 September 2015); Ruys, supra note 12, at 36ff.

${ }^{19}$ See also Talmon, 'Recognition of Opposition Groups As the Legitimate Representative of a People', 12 ChJIL (2013) 232; Ruys, supra note 12, at 37; Akande, supra note 12, para. 4.

${ }^{20}$ Tinoco Claims Arbitration (Great Britain v. Costa Rica), Decision of 18 October 1923, reprinted in UNRIAA, vol. 1, 369; Talmon, supra note 19, at 232; D. Akande, 'Recognition of Libyan National Transitional Council As Government of Libya', EJIL:Talk! (23 July 2011), available at http://www.ejiltalk.org/ (last visited 20 September 2015).

${ }^{21}$ Roth, 'Secessions, Coups and the International Rule of Law: Assessing the Decline of the Effective Control Doctrine', 11 Melbourne Journal of International Law (2010) 2; Doswald-Beck, 'The Legal Validity of Military Intervention by Invitation of the Government', 56 British Yearbook of International Law (BYIL) (1985) 194.

${ }^{22}$ Wippman, supra note 3, at 212; Roth, supra note 21, at 37; Talmon, supra note 19, at 233.

${ }^{23}$ Roth, supra note 21 , at 2, 31.

${ }^{24}$ Wippman, supra note 3 , at 212.

${ }^{25}$ See extensively Talmon, supra note 9, at 3ff. See also Doswald-Beck, supra note 21, at 194.

${ }^{26}$ Wippman, supra note 3, at 212; G. Fox, 'Ukraine Intra-Symposium: Intervention in the Ukraine by Invitation', Opinio Juris (10 March 2014), available at http://opiniojuris.org/ (last visited 20 September 2015).

${ }^{27}$ SC Res. 837, 25 May 1993 (establishment of the International Criminal Tribunal for the former Yugoslavia [ICTY]); SC Res. 955, 8 November 1994 (establishment of the International Criminal Tribunal for Rwanda [ICTR]); see also Saul, 'From Haiti to Somalia: The Assistance Model and the Paradox of State Reconstruction in International Law', 11 International Community Law Review (2009) 138; Roth, supra note 21, at 2. 
${ }^{28}$ See Franck, 'The Emerging Right to Democratic Governance', 86 AJIL (2002) 46; Reisman, 'Sovereignty and Human Rights in Contemporary International Law', in G.H. Fox and B.R. Roth (eds), Democratic Governance and International Law (2000) 239, at 239ff; Slaughter, A New World Order (2004); D’Asperemont, 'Legitimacy of Governments in the Age of Democracy', 38 NYJILP (2006) 877; G.H. Fox and B.R. Roth, Democratic Governance and International Law (2010); Marks, 'What Has Become of the Emerging Right to Democratic Governance?', 22 European Journal of International Law (2011) 507.

${ }^{29}$ J. Vidmar, Democratic Statehood in International Law (2013) 15.

${ }^{30}$ Nowrot and Schabacker, 'The Use of Force to Restore Democracy: International Legal Implications of the ECOWAS Intervention in Sierra Leone', 14 American University International Law Review (1998) 321. See also Wippman, supra note 3, at 216; Roth, supra note 21, at 36.

${ }^{31}$ See, e.g., the preamble of SC Res. 841, 16 June 1993, regarding Haiti; SC Res. 1132, 8 October 1997, para. 1, regarding Sierra Leone.

${ }^{32}$ Talmon, supra note 9, at 10; Roth, supra note 21 , at 37.

${ }^{33}$ See their final communiqué of the meeting, UN Doc. S/1997/499, 27 June 1997, Annex, at 3; UN Doc. S/1997/695, 8 September 1997, at Annex I and Annex 2. See also G. Nolte, Eingreifen auf Einladung (1999) 426-427; De Wet, 'The Evolving Role of ECOWAS and the SADC in Peace Operations: A Challenge to the Primacy of the United Nations Security Council in Matters of Peace and Security?', 27 LIL (2014) 361-362.

${ }^{34}$ SC Res. 1162, 17 April 1998, para. 2; SC Res. 1181, 13 July 1998, paras 6, 9; SC Res. 1260, 20 August 1999, para. 3; SC Res. 1231, 11 March 1999, para. 10; SC Res. 1270, 22 October 1999, para. 7; SC Res. 1289, 7 February 2000, para. 2; SC Presidential Statement 5, 26 February 1998. See also De Wet, supra note 33, at 362-363.

${ }^{35}$ Franck, 'Rethinking Collective Security', in M. Schmitt and J. Peijc (eds), International Law and Armed Conflict: Exploring the Faultlines: Essays in Honour of Yoram Dinstein (2007) 25; see also Levitt, 'Humanitarian Intervention by Regional Actors in Internal Conflicts: The Case of ECOWAS in Liberia and Sierra Leone', 12 Temple Journal of International and Comparative Law (1998) 369, who suggested various legal bases for the intervention.

${ }^{36}$ SC Res. 940, 31 July 1994, was finally adopted almost three years after the coup in September 1991; Wippman, supra note 3, at 216; Nowrot and Schbacker, supra note 30, at 397, 399.

${ }^{37}$ Declaration of Lima: Inter-American Democratic Charter, OAS GA Res. 1 (XXVIII-E/01), OAS Doc. OEA/SerP/ AG/Res 1 (XXVIII-E/01), 11 September 2001, at Art. 19. For an analysis of the developments within the Organization of American States (OAS) that led up to this declaration, see Roth, supra note 21, at $39 \mathrm{ff}$.

${ }^{38}$ This remained the case, despite the fact that President Zeleya was internally marginalized by the time of the coup, and his claims to the presidency were also rejected by the judiciary and the legislative. Roth, supra note 21 , at $41,43$.

39 Ibid., at 41, 43; Talmon, supra note 9, at 13.

${ }^{40}$ However, Art. 4(p) does not provide a separate ground for military intervention in an African Union (AU) member state. See De Wet 'Regional Organisations and Arrangements and Their Relationship with the United Nations: The Case of the African Union', in Marc Weller (ed.), The Oxford Handbook on the Use of Force (2015) 314, s. 4.4.

${ }^{41}$ African Charter on Democracy, Elections and Governance (African Charter) (opened for signature on 30 January 2007, Addis Ababa), available at www.au.int/en/content/african-charter-democracy-elections-andgovernance (last visited 20 September 2015). 
${ }^{42}$ The African Charter has entered into force for Burkina Faso, Cameroon, Chad, Ethiopia, Ghana, Guinea, Guinea-Bissau, Lesotho, Mauritania, Niger, Nigeria, Rwanda, Sierra Leone, South Africa, Zambia. See Insitute for Democracy in Africa, ' 15 Ratifications of the AU Charter on Democracy, Elections and Governance', Polity (2 February 2012), available at www.polity.org.za/article/15-ratifications-of-the-au-charter-on-democracyelections-and-governance-2012-02-01 (last visited 20 September 2015).

${ }^{43}$ Z. Yihdego, 'Democracy, Peoples' Uprising and Unconstitutional Change of Government in Egypt: The African Union Principles and Responses', EJIL: Talk! (8 July 2013), available at www.ejiltalk.org/ (last visited 20 September 2015).

${ }^{44}$ These included Burkina Faso, Central African Republic, Equatorial Guinea, The Gambia, Guinea, Libya, Sudan and Tunisia. See Roth, supra note 21, at 46; see also Yihdego, supra note 43.

${ }^{45}$ See, e.g., South Africa's criticism of the North American Treaty Organization's (NATO) interpretation of its mandate in Ulfstein, 'The Legality of the NATO Bombing in Libya', 62 International and Comparative Law Quarterly (ICLQ) (2013) 167.

${ }^{46}$ AU Peace and Security Council, 297th Meeting, Communiqué, Doc. PSC/PR/COMM/2.(CCXCVII), 20 October 2011, para. 4, available at www.peaceau.org/en/ (last visited 20 September 2015).

${ }^{47}$ These countries also took the unusual step of explicitly de-recognizing the Qaddafi regime. See Fourth Meeting of the Libya Contact Group, Chair's Statement, 15 July 2011, para. 4, available at www.mfa.gov.tr/fourth-meeting-of-the-libya-contact-group-chair_s-statement_-15-july-2011_-istanbul.en.mfa (last visited 20 September 2015). See also Talmon, 'De-Recognition of Colonel Qaddafi as Head of State of Libya?', 60 ICLQ (2011) 759.

${ }^{48}$ Talmon, supra note 19, at 233.

${ }^{49}$ Akande, supra note 20.

${ }^{50}$ GA Res. 66/1/A, 16 September 2011.

${ }^{51}$ Yihdego, supra note 43.

${ }^{52}$ Ibid.

${ }^{53}$ AU Peace and Security Council, Communiqué, 384th Meeting, Doc. PSC/PR/COMM (CCCLXXXIV), 5 July 2013, para. 6, available at www.peaceau.org/en/ (last visited 20 September 2015).

${ }^{54}$ BBC, 'World Reaction to the Ousting of Egypt's Mohammed Morsi', BBC News (4 July 2013), available at www.bbc.com/news/world-middle-east-23175379 (last visited 20 September 2015).

${ }^{55}$ See, e.g., AU Peace and Security Council, 318th Meeting at the Level of Heads of State and Government, Doc. PSC/PR/COMM (CCCXVIII), 17 April 2012, paras 3ff, available at www.peaceau.org/en/ (last visited 20 September 2015).

${ }^{56}$ Institute for Security Studies, Peace and Security Report, vol. 45 (2013) 8-9; see also Communiqué, Extraordinary Summit of the Authority of the Economic Community of West African States (ECOWAS) Head of State and Government, 3 May 2012, paras 19ff, available at http://documentation.ecowas.int/ (last visited 20 September 2015).

${ }^{57}$ The United Nations Security Council (UNSC), for its part, condemned the coup in Guinea-Bissau. See SC Res. 2048, 18 May 2012, paras 1, 4 See also European Union (EU), Conclusions of the Council on Guinea-Bissau, Brussels, Doc. 9010/12, 31 May 2012, at paras 1ff. 
${ }^{58}$ See Extraordinary Summit of the ECOWAS Head of State and Government, Final Communiqué, 26 April 2012, paras 9ff, available at http://documentation.ecowas.int/ (last visited 20 September 2015); Institute for Security Studies, ECOWAS Peace and Security Report Series, Mali: Making Peace While Preparing for War (October 2012), at 2, available at www.issafrica.org (last visited 20 September 2015).

${ }^{59}$ See AU Peace and Security Council, 332nd Meeting, Communiqué, Doc. PSC/PR/COMM (CCCXXXII), 4 September 2012, para. 3, available at www.peaceau.org/en/ (last visited 20 September 2015); see also Bannelier and Christakis, supra note 3, at 865. Finally, in August 2013, elections were held, and President Ibrahim Keita was elected president. See 'Mali Dismisses Candidates for Fraud in Elections', Reuters (1 January 2014), available at www.reuters.com/article/2014/01/01/us-mali-elections-idUSBREA000KK20140101 (last visited 20 September 2015).

${ }^{60}$ AU Peace and Security Council, 363rd Meeting, Communiqué, Doc. PSC/PR/COMM (CCCLXIII), 25 March 2013, paras 6ff, available at www.peaceau.org/en/ (last visited 20 September 2015). The designation by the National Transitional Council of Catherine Samba-Panza as transitional head of state in January 2014 was welcomed by the international community. See SC Res. 2149, 10 April 2014, para. 1.

${ }^{61}$ Z. Vermeer, 'Intervention with the Consent of a Deposed (but Legitimate) Government? Playing the Sierra Leone card', EJILTalk! (6 March 2014), available at www.ejiltalk.org/ (last visited 20 September 2015); see also N. Krisch, 'Crimea and the Limits of International Law', EJILTalk! (10 March 2014). available at www.ejiltalk.org/ (last visited 20 September 2015); D. Wisehart, 'The Crisis in the Ukraine and the Prohibition of the Use of Force: A Legal Basis for Russia's Intervention?', EJILTalk! (4 March 2014), available at www.ejiltalk.org/ (last visited 20 September 2015).

${ }^{62}$ GA Res. 68/262, 27 March 2014.

${ }^{63}$ See Vermeer, supra note 61. GA Res. 262, 27 March 2014, para. 6; Fox, supra note 26.

${ }^{64}$ See Roth, supra note 21, at 43. See also Nolte, 'The Resolution of the Institut de Droit International on Military Assistance on Request', 45 Revue belge de droit international (2012) 256. He noted a retreat from the idea that democratic legitimacy is a condition for recognition of a government and its right to request military assistance, since its postulation in the early 1990 s.

${ }^{65}$ Wippman, supra note 3, at 214.

${ }^{66}$ Ibid., at 220; Doswald-Beck, supra note 21, at 199.

${ }^{67}$ Nowrot and Schbacker, supra note 30, at 390.

${ }^{68}$ Ibid., at 390.

${ }^{69}$ President Doe stated that 'it would seem most expedient at this time to introduce an ECOWAS Peacekeeping Force into Liberia to forestall increasing terror and tension and to assure a peaceful transitional environment'. See Letter addressed by President Samuel K. Doe to the Chairman and Members of the Ministerial Meeting of ECOWAS Standing Mediation Committee, Doc. 39, 14 July 1990, reprinted in M. Weller (ed.), Regional Peace-keeping and International Enforcement: The Liberian Crisis (1994) 61.

${ }^{70}$ See Nolte, supra note 33, at 429-430; Wippman, supra note 3, at 224; Birikorang, 'Lessons Learned and Best Practice from a Troubled Region: ECOWAS and the Development of the ECOWAS Standby Force', in U. Engel and J. Gomes Porto (eds), Towards an African Peace and Security Regime (2013) 92.

${ }^{71}$ The ECOWAS Standing Meditation Committee, inter alia, stated that, 'presently, there is a government in Liberia which cannot govern and contending factions which are holding the entire population as hostage, depriving them of food, health facilities and other basic necessities of life'. See ECOWAS Standing Mediation Committee, Banjul, Republic of Gambia, Final Communiqué of the First Session, Doc. 54,7 August 1990, 
reprinted in Weller, supra note 69,72 . See also Levitt, supra note 35 , at $342 \mathrm{ff}$. There were also authors who suggested that the intervention was authorized ex post facto by the UNSC, e.g., Österdahl, 'The Continued Relevance of Collective Security under the UN: The Security Council, Regional Organisations and the General Assembly', 10 Finnish Yearbook of International Law (1999) 57.

${ }^{72}$ AU Peace and Security Council, 69th Meeting, Communiqué, Doc. PSC/PR/Comm (LXIL), 19 January 2007, available at www.peaceau.org/en/ (last visited 20 September 2015). For the legal basis of those missions immediately preceding AMISON in Somalia, see De Wet, supra note 40, s. 4.3.

${ }^{73}$ A few weeks after the establishment of the African Union Mission in Somalia (AMISON), its mandate was also endorsed by SC Res. 1744, 21 February 2007, paras 4, 12. As this resolution was adopted under Chapter VII of the UN Charter, it placed the mandate on a different legal basis. See De Wet, supra note 40, s. 4.3; Saul, supra note 27 , at 138 .

${ }^{74}$ The Malian government was still in control of the South and the capital of Bamako. See Bannelier and Christakis, supra note 3 , at 865 .

${ }^{75}$ See the joint statement on behalf of the United States, Britain and France by B. Obama, D. Cameron, and N. Sarkozy, 'Libya's Pathway to Peace', New York Times (14 April 2011), available at www.nytimes.com/2011/04/15/opinion/15iht-edlibya15.html?_r=0 (last visited 20 September 2015). For an overview of the different opinions of states, see Ulfstein, supra note 45 , at $165 \mathrm{ff}$.

${ }^{76}$ Statement by Secretary of Defense Chuck Hagel on the Signing of the Bilateral Security Agreement, Department of Defense News, Doc. NR-499-14, 30 September 2014, available at www.defense.gov/releases/release.aspx?releaseid=16958 (last visited 20 September 2015).

${ }^{77}$ See Agreement on Provisional Arrangements in Afghanistan Pending the Reestablishment of Permanent Government Institutions, annexed to UN Doc. S/2001/1154, 5 December 2001.

${ }^{78}$ See Jonathan Beale, 'Iraq Formally Asks US to Launch Air Strikes against Rebels', BBC News (18 June 2014), available at www.bbc.com/news/world-middle-east-27905849 (last visited 20 September 2015).

${ }^{79}$ See Doswald-Beck, supra note 21, at 199.

${ }^{80}$ See United Kingdom Foreign Policy Doc. 148, Part II.7, reprinted in 57 BYIL (1986) 614; Le Mon, supra note 3, at 753; C. Gray, International Law and the Use of Force (3rd edn, 2008) 67, 81; Ruys, supra note 12, at 39, 43; Akande, supra note 12 , para. 3.

${ }^{81}$ S. Sivakumaran, The Law of International Armed Conflict (2012) 9-10; Le Mon, supra note 3, at 746.

${ }^{82}$ See extensively Sivakumaran, supra note 81 , at 11 . Recognition of belligerency by the parent state resulted in the application of the law of war to the violence, while recognition by third states to the application of the law of neutrality. Le Mon, supra note 3, at 746-747. See also D. Fleck, The Handbook of International Humanitarian Law (3rd edn, 2013), at 581.

${ }^{83}$ Le Mon, supra note 3, at 747-748; Sivakumaran, supra note 81, at 10.

${ }^{84}$ Sivakumaran, supra note 81, at 161. Geneva Conventions 1949, 1125 UNTS 3.

${ }^{85}$ Final Record of the Diplomatic Conference of Geneva of 1949, Vol. II-B (1949), at 192; Sivakumaran, supra note 81 , at 161 .

${ }^{86}$ Sivakumaran, supra note 81 , at $161-162$. 
${ }^{87}$ Protocol Additional to the Geneva Conventions of 12 August 1949, and Relating to the Protection of Victims of Non-International Armed Conflicts (Additional Protocol II) 1977, 1125 UNTS 609, Arts 1(1) and 1(2) determines that ' 1 . This Protocol, which develops and supplements Article 3 common to the Geneva Conventions of 12 August 1949 without modifying its existing conditions of application, shall apply to all armed conflicts ... which take place in the territory of a High Contracting Party between its armed forces and dissident armed forces or other organized armed groups which, under responsible command, exercise such control over a part of its territory as to enable them to carry out sustained and concerted military operations and to implement this Protocol. 2. This Protocol shall not apply to situations of internal disturbances and tensions, such as riots, isolated and sporadic acts of violence and other acts of a similar nature, as not being armed conflicts.' See also Judgment, Tadić (IT-94-1-T), Trial Chamber, 7 May 1997, para. 562; David, 'International (Non-International) Armed Conflict)', in A. Clapham and P. Gaeta (eds), The Oxford Handbook of International Law in Armed Conflict (2014) 356.

${ }^{88}$ See Decision on the Defence Motion for Interlocutory Appeal on Jurisdiction, Tadić (IT-94-1-T), Appeals Chamber, 2 October 1995, paras 128-134; Judgment, Aleksovski (IT-95-14/1) Trial Chamber, 25 June 1999, para. 43; Judgment, Jelisić (IT-95-10), Trial Chamber, 14 December 1999, para. 29; David, supra note 87, at 357.

${ }^{89}$ See, e.g., Judgment, Limaj et al (IT-03-66), Trial Chamber, 30 November 2005, paras 90ff; Judgment, Kayishema and Ruzindana (ICTR-95-1-T), Trial Chamber, 21 May 1999, para. 174; Decision on the Confirmation of Charges, Katanga et Ngudjolo Chui (ICC-01/04-01/07), Pre-Trial Chamber, 30 September 2008, para. 239; David, supra note 87, at 359-361.

${ }^{90}$ GA Res. 375 (IV), 6 December 1949, at Art. 4; Gray, supra note 80, at 67.

${ }^{91}$ Le Mon, supra note 3, at 752; see also GA Res. 2131 (XX), 21 December 1965, para. 2.

${ }^{92}$ GA Res. 2625 (XXV), 24 October 1970. The customary status of the resolution has been confirmed in Nicaragua, supra note 10, para. 191 and in Armed Activities on the Territory of the Congo (Democratic Republic of the Congo v. Uganda), Judgment, 19 December 2005, ICJ Reports (2005) 168, at para. 162. See also Gray, supra note 80, at 68; Le Mon, supra note 3, at 753.

93 IDI, Resolution on the Principle of Non-Intervention in Civil Wars, supra note 2, at Art. 2.

${ }^{94}$ IDI, Resolution on Military Assistance on Request, supra note 2, at Art. 2(1) and Art. 4(4).

${ }^{95}$ Western Sahara, Advisory Opinion, 16 October 1975, ICJ Reports (1975) 12, at para. 55; see generally Vidmar, supra note 29 , at $169 \mathrm{ff}$.

${ }^{96}$ Doswald-Beck, supra note 21, at 207; Bannelier and Christakis, supra note 3, at 861.

${ }^{97}$ Doswald-Beck, supra note 21, at 207-208.

${ }^{98}$ Nicaragua, supra note 10, at paras 202, 205

${ }^{99}$ See, in particular, Doswald-Beck, supra note 21, at 203.

${ }^{100}$ Doswald-Beck, supra note 21, at 207; Perkins, supra note 4, at 186 . Although the right to non-intervention exists separately from the prohibition of the use of force, the two norms can go hand in hand. See Nicaragua, supra note 10, para. 205

${ }^{101}$ See, e.g., International Covenant on Civil and Political Rights 1966, 999 UNTS 171. See extensively Vidmar, supra note 29 , at $143 \mathrm{ff}$. 
102 Le Mon, supra note 3 , at 746.

${ }^{103}$ Bannelier and Christakis, supra note 3, at 861; Nolte, supra note 33, at 245-246. See also Perkins, supra note 4, at 189, 192 and 221, who suggest that an illegal intervention on behalf of the government can give rise to a right to a countermeasure in the form of a counter-intervention.

${ }^{104}$ Bannelier and Christakis, supra note 3, at 861. Wippman, supra note 3, at 212, 216.

${ }^{105}$ Perkins, supra note 4 , at 189

106 Ibid., at 189.

${ }^{107}$ Gray, supra note 80 , at 82 .

108 Ibid., at 86 .

${ }^{109}$ See Ruys, supra note 12 , at 44.

${ }^{110}$ Congo v. Uganda, supra note 92, paras 46ff, 208-221; Nolte, supra note 64 , at 261 , Gray, supra note 80 , at 87.

${ }^{111}$ SC Presidential Statement 16, 8 August 2014.

${ }^{112}$ SC Res. 2085, 20 December 2012, para. 9(b).

${ }^{113}$ Bannelier and Christakis, supra note 3, at 857-858.

${ }^{114}$ Letter from the Permanent Representative of France to the UN Addressed to the Secretary-General and the President of the UNSC, Doc. S/1013/17, 11 January 2013; see also Bannelier and Christakis, supra note 3, at 859.

${ }^{115}$ Bannelier and Christakis, supra note 3, at 866.

${ }^{116}$ Ibid., at 866 .

${ }^{117}$ Ibid., at 867 who stated that the French intervention was not against the National Movement for the Liberation of Azawad, as the French government supported a political solution for the Tuareg problem. See also www.mnlamov.net (last visited 20 September 2015).

${ }^{118}$ Bannelier and Christakis, supra note 3, at 867.

119 Ibid., at 859.

${ }^{120}$ Statement of the President of ECOWAS Commission on the Situation in Mali, 12 January 2013, available at www.news/ecowas.int/presseshow.php?nb=006\&lang=en\&annee2013 (last visited 20 September 2015); Bannelier and Christkakis, supra note 3, at 869.

${ }^{121}$ SC Res. 2100, 13 April 2013, paras 16-18 provided a Chapter VII authorization for future military action in Mali by the United Nations Multidimensional Integrated Stabilization Mission in Mali as well as by the French forces (where their assistance was requested by the UNSC). See also Bannelier and Christakis, supra note 3 , at 867-868.

122 See Statement by Secretary of Defense Chuck Hagel, supra note 76; G.D. Solis, The Law of Armed Conflict: International Humanitarian Law in War (2010), at 153. 
${ }^{123}$ SC Res. 2169, 30 July 2014.

${ }^{124}$ In the same vein, in the Syria conflict, no state has thus far suggested that indirect state support (notably Russian) in the form of arms to the Assad government is illegal. Ruys, supra note 12, at 44.

125 Ibid., at 46; Wippman, supra note 3, at 220-221; Perkins, supra note 4, at 203ff.

${ }^{126}$ Wippman, supra note 3, at 220-221; Gray, supra note 80 , at 92.

${ }^{127}$ Gray, supra note 80 , at 69.

${ }^{128}$ In 1999, Angola, Namibia, Zimbabwe and the Democratic Republic of Congo concluded a defence pact; see De Wet, supra note 33 , at 367. 